\title{
Lasting false beliefs and their behavioral consequences
}

Citation for published version (APA):

Geraerts, E. G., Bernstein, D., Merckelbach, H. L. G. J., Linders, C., Raymaekers, L. H. C., \& Loftus, E. F. (2008). Lasting false beliefs and their behavioral consequences. Psychological Science, 19(8), 749-753. https://doi.org/10.1111/j.1467-9280.2008.02151.x

Document status and date:

Published: 01/01/2008

DOI:

10.1111/j.1467-9280.2008.02151.x

Document Version:

Publisher's PDF, also known as Version of record

\section{Please check the document version of this publication:}

- A submitted manuscript is the version of the article upon submission and before peer-review. There can be important differences between the submitted version and the official published version of record.

People interested in the research are advised to contact the author for the final version of the publication, or visit the DOI to the publisher's website.

- The final author version and the galley proof are versions of the publication after peer review.

- The final published version features the final layout of the paper including the volume, issue and page numbers.

Link to publication

\footnotetext{
General rights rights.

- You may freely distribute the URL identifying the publication in the public portal. please follow below link for the End User Agreement:

www.umlib.nl/taverne-license

Take down policy

If you believe that this document breaches copyright please contact us at:

repository@maastrichtuniversity.nl

providing details and we will investigate your claim.
}

Copyright and moral rights for the publications made accessible in the public portal are retained by the authors and/or other copyright owners and it is a condition of accessing publications that users recognise and abide by the legal requirements associated with these

- Users may download and print one copy of any publication from the public portal for the purpose of private study or research.

- You may not further distribute the material or use it for any profit-making activity or commercial gain

If the publication is distributed under the terms of Article $25 \mathrm{fa}$ of the Dutch Copyright Act, indicated by the "Taverne" license above, 


\title{
Research Report
}

\section{Lasting False Beliefs and Their Behavioral Consequences}

\author{
Elke Geraerts, ${ }^{1,2}$ Daniel M. Bernstein, ${ }^{3,4}$ Harald Merckelbach, ${ }^{2}$ Christel Linders, ${ }^{2}$ Linsey Raymaekers, ${ }^{2}$ \\ and Elizabeth F. Loftus ${ }^{5}$ \\ ${ }^{1}$ University of St. Andrews, ${ }^{2}$ Maastricht University, ${ }^{3}$ Kwantlen University College, ${ }^{4}$ University of Washington, and \\ ${ }^{5}$ University of California, Irvine
}

\begin{abstract}
False beliefs and memories can affect people's attitudes, at least in the short term. But can they produce real changes in behavior? This study explored whether falsely suggesting to subjects that they had experienced a food-related event in their childhood would lead to a change in their behavior shortly after the suggestion and up to 4 months later. We falsely suggested to 180 subjects that, as children, they had gotten ill after eating egg salad. Results showed that, after this manipulation, a significant minority of subjects came to believe they had experienced this childhood event even though they had initially denied having experienced it. This newfound autobiographical belief was accompanied by the intent to avoid egg salad, and also by significantly reduced consumption of egg-salad sandwiches, both immediately and 4 months after the false suggestion. The false suggestion of a childhood event can lead to persistent false beliefs that have lasting behavioral consequences.
\end{abstract}

Laboratory research has demonstrated that human memory can be remarkably fragile and even inventive. Studies on false memories and beliefs, for example, have compellingly shown that misleading information can lead to the creation of recollections of entire events that have not occurred (Loftus, 2005). In one of the first studies on this issue, subjects were led to believe that when they were children, they had been lost in the shopping mall for an extended period of time before being reunited with their parents (Loftus \& Pickrell, 1995). In subsequent work, subjects falsely remembered even more unusual or upsetting events, such as spilling a punch bowl at a wedding (Hyman, Husband, \& Billings, 1995), having a ride in a hot-air balloon

Address correspondence to Elke Geraerts, University of St. Andrews, School of Psychology, St. Mary's Quadrangle, St. Andrews, Fife KY16 9JP, United Kingdom, e-mail: elke.geraerts@st-andrews. ac.uk.
(Wade, Garry, Read, \& Lindsay, 2002), or even having been hospitalized as a child (Raymaekers, 2005).

Salient real-life examples of misremembering the past are cases in which people have falsely recovered memories of childhood sexual abuse, often instigated by suggestive therapeutic techniques (Geraerts et al., 2007; Loftus \& Davis, 2006). People also claim to have recovered memories of more inconceivable experiences, including memories involving satanicritual abuse (Scott, 2001), previous lives (Peters, Horselenberg, Jelicic, \& Merckelbach, 2007), and abduction by space aliens (Clancy, 2005), and such memories are often recovered during suggestive therapy as well. Even though such memories may not be real, they sometimes cause emotional pain similar to that of people who have experienced a traumatic event (McNally et al., 2004). This can have behavioral consequences, such as suing the alleged perpetrator after recovering memories of childhood abuse.

Strikingly, although a clear link between beliefs and behavior has been found repeatedly (Ajzen, 2005), laboratory research, until now, has not examined the possible effects of false memories on behavior. Can false beliefs be sufficiently strong to alter behavior? If one develops false memories in the laboratory, might they have an influence on one's short- and long-term attitudes and actions? Recently, Bernstein, Laney, Morris, and Loftus (2005a, 2005b) took the first steps toward answering this question by developing a procedure for examining the effects of false childhood memories and beliefs. Their subjects received the false suggestion that they had become ill after eating a certain food (e.g., hard-boiled eggs, strawberry ice cream) when they were children. The false suggestion increased subjects' confidence that the critical event had occurred. Moreover, the false belief resulted in decreased self-reported preference for the target food and increased anticipated behavioral avoidance of that food.

These findings clearly demonstrate that false beliefs can influence attitudes. A remaining question, though, is whether false beliefs or memories produce real changes in behavior. The 
current study explored whether falsely suggesting to subjects that they had experienced a food-related event in their childhood would lead to a quantifiable change in their behavior. Moreover, we examined whether lasting false beliefs can have long-term consequences with respect to particular eating habits. We falsely suggested to subjects that, as children, they had become ill after eating egg salad. We then examined whether this suggestion increased their confidence that this event had occurred and whether they avoided the target food, in both the short and the long term (i.e., after 4 months).

\section{METHOD}

\section{Subjects}

The subjects were 180 first-year undergraduates (135 women, 45 men; average age $=20.99, S D=2.76$ ) at Maastricht University in The Netherlands. Subjects were all screened to ensure that they did not have eating disorders. We randomly assigned subjects to one of two groups: Subjects in the egg-salad group $(n=120)$ received the false suggestion that they had gotten sick after eating egg salad as a child. The remaining 60 subjects were in the control group and did not receive this false suggestion. All instructions were given in Dutch.

\section{Materials and Procedure}

Subjects initially signed up for a study called "Food and Personality." After 4 months, they were recontacted by a different experimenter, who asked them to enroll in an allegedly separate study.

During the first session, subjects completed a 24-item foodhistory inventory (Bernstein et al., 2005b) containing the critical event, "got sick after eating egg salad." They rated whether or not each event on this inventory happened to them before their 10th birthday, using a scale ranging from 1 (definitely did not happen) to 8 (definitely did happen). Subjects also completed a questionnaire about their food preferences, rating how much they liked to eat 62 different foods, including egg salad. Finally, subjects imagined being at a party with a variety of foods and beverages available and indicated their likelihood of consuming each of 20 options, including the critical item, egg salad.

During the second session, which occurred exactly 1 week later, subjects received false feedback about their responses to the questionnaires that they had completed during the first session. We falsely told subjects that we had entered their responses into a computer that had then generated a profile of their early childhood experiences with certain foods. We told subjects that, as young children, they disliked Brussels sprouts, enjoyed eating pizza, and felt happy when a classmate brought sweets to school. Additionally, subjects in the egg-salad group were told, "You got sick after eating egg salad." To ensure that subjects in this group thought about this feedback, we told them that the computer randomly selected one feedback item for them to elaborate on, and that the item was egg salad (for a detailed description of the materials and procedure, see Bernstein et al., 2005a). Control subjects responded to a filler item.

After this elaboration phase, subjects again completed the food-history inventory, food-preferences questionnaire, and party-behavior questionnaire. Responses on these questionnaires were used to determine whether there were changes in (a) subjects' confidence that the critical event had happened in their childhood and (b) their avoidance of the critical item. Subjects also completed a memory-belief form with questions pertaining to three events from the food-history inventory, including the critical item. They were asked to indicate whether they had a specific belief or memory of each of these events from before age 10. If they had a specific memory of an event, they wrote "M" and gave as many details as possible, and if they believed the event happened but had no specific memory of it, they wrote "B" and explained why they believed the event happened. If they were positive that the event did not happen, they wrote "P" and explained why they were so sure that the event did not happen.

Finally, subjects were taken in small groups to another room, where they received a bogus debriefing. In the beginning of this 15-min period, subjects were told that the researchers wanted to thank them for their participation by providing a treat, and a catering company brought in drinks and sandwiches with five different fillings: egg salad (critical item), tuna salad, chicken salad, cheese, and ham. While the alleged debriefing was given, the experimenter, who did not know the group to which each subject had been assigned, recorded what type of sandwiches the subjects chose.

After 4 months, another experimenter recontacted the subjects to recruit them for an allegedly separate study at another laboratory at Maastricht University. In total, 153 (85\%) subjects agreed to participate. They were told that this study (in reality, the third session) involved a taste test designed to examine people's preferences for certain types of food. The procedure of this taste test was adapted from the methods of Herman and Polivy (1980).

Subjects were asked to evaluate five different types of fruitflavored water (lime, raspberry, tropical punch, apple, and tangerine) and five types of sandwiches (ham, cheese, chicken salad, tuna salad, and egg salad), using 8-point scales to rate them for appearance, smell, flavor, and food preference. While preserving quantity, we ensured that the sandwiches had a different appearance than in the second session so as not to remind subjects of that session. Next, subjects were instructed to complete three (filler) questionnaires. They were also told that the residual food would be thrown away, and that they should feel free to consume as much as they wanted. After $15 \mathrm{~min}$, the food was removed. Subjects then again completed the food-history inventory, food-preferences questionnaire, partybehavior questionnaire, and memory-belief form. We changed the layout of all these questionnaires so as to disguise the link with the previous sessions. 
After completing the questionnaires, subjects were asked what they thought the purpose of the new study was and whether they thought the third session was a study separate from the first two sessions. Only 5 subjects ( 1 in the egg-salad group, 4 in the control group) reported that the study was about memory, and no subjects reported that the study was about false memories. ${ }^{1}$ Thus, the contributions of social desirability to the results were minimized. ${ }^{2}$ All subjects thought the sessions were unrelated. Finally, subjects were debriefed about the entire research project. They were also asked whether we could verify with their parents if they might have truly gotten sick from eating egg salad as a child.

\section{RESULTS}

Subjects were considered to have arguably true memories (a) if they both scored above the midpoint for the critical item on the food-history inventory during the first session and reported a belief or memory for the critical egg-salad event or (b) if their parents confirmed that they had gotten sick after eating egg salad as a child. Five subjects met these criteria ${ }^{3}$ and were excluded from analyses. After these subjects were excluded, the remaining sample consisted of 117 subjects in the experimental group and 58 subjects in the control group. Next, in the eggsalad group, we identified subjects who were believers $(n=41)$ and nonbelievers ( $n=58$; see Morris, Laney, Bernstein, \& Loftus, 2006). Subjects were considered believers if they met two criteria: Their confidence that the critical event happened had to increase after they received the false feedback, and they had to report a memory or belief related to the critical event on the memory-belief form (3 believers, $7 \%$, reported a memory, rather than a belief). Nonbelievers were subjects whose confidence that the critical egg-salad event had happened remained the same or decreased after they received the false feedback. Of the 153 subjects who returned to the lab for the third session, 35 were believers, 54 were nonbelievers, and 50 were control subjects.

\section{Confidence and Preference}

Results for the attitudinal measures replicated previous findings (e.g., Bernstein et al., 2005a): Although responses to the foodhistory inventory showed no group differences in subjects' initial confidence that the critical egg-salad event had happened, responses in both the second and the third sessions, after subjects in the egg-salad group had received the false feedback, indicated that believers were significantly more confident that

${ }^{1}$ Excluding these subjects from analyses did not change the results. Note that no subjects had yet completed courses on memory or false memory.

${ }^{2}$ Previous findings showed that social desirability could not account for significant variance in effects of false beliefs on attitudes (e.g., Laney, Bowman Fowler, Nelson, Bernstein, \& Loftus, in press).

${ }^{3}$ The egg-salad memories of all 5 subjects who met the first criterion were also confirmed by their parents.

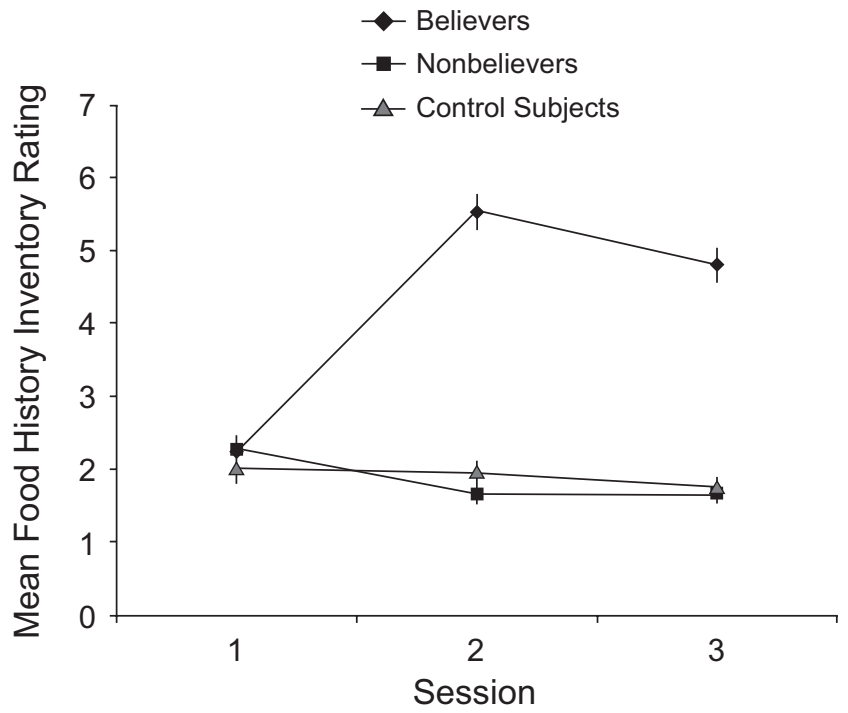

Fig. 1. Subjects' mean confidence that they had gotten ill after eating egg salad as a child, as a function of session. Session 1 was before the false suggestion, Session 2 was 1 week later, and Session 3 was 4 months later. Results are shown separately for subjects who believed the false suggestion, subjects who did not believe the false suggestion, and control subjects (who were not exposed to the false suggestion). Error bars represent standard errors of the means.

they had gotten sick from eating egg salad than nonbelievers and control subjects were, all $t \mathrm{~s}>11.73$, all $p \mathrm{~s}<.001$ (see Fig. 1). Between the first and second sessions, believers' confidence that they had experienced this event increased an average of 3.29 points on the 8-point scale, $t(40)=11.95, p<.001, d=2.32$.

Also, in both sessions after the false feedback, believers reported significantly less preference for egg salad on the food-preferences and party-behavior questionnaires than did nonbelievers and control subjects. Finally, during the taste testing in the third session, believers gave the egg-salad sandwiches lower ratings for appearance and flavor than did nonbelievers and control subjects. ${ }^{4}$

\section{Eating Behavior}

The critical findings concerned whether the false suggestion affected actual eating behavior. In fact, the groups differed in the number of egg-salad sandwiches eaten in the second session, $F(2,154)=12.45, p<.001, \eta^{2}=.14$, and in the third session, $F(2,136)=3.55, p=.031, \eta^{2}=.05$. Specifically, in the second session, believers and nonbelievers both ate fewer egg-salad sandwiches than did control subjects, $t(97)=3.10, p=.003$, $d=0.63$, and $t(114)=4.32, p<.001, d=0.81$, respectively, but the numbers of egg-salad sandwiches eaten by believers and nonbelievers did not differ significantly $(t<1)$. In the third session, believers ate fewer egg-salad sandwiches than did both nonbelievers, $t(87)=2.08, p=.041, d=0.44$, and control

\footnotetext{
${ }^{4}$ Complete reports of the analyses are available from the first author.
} 


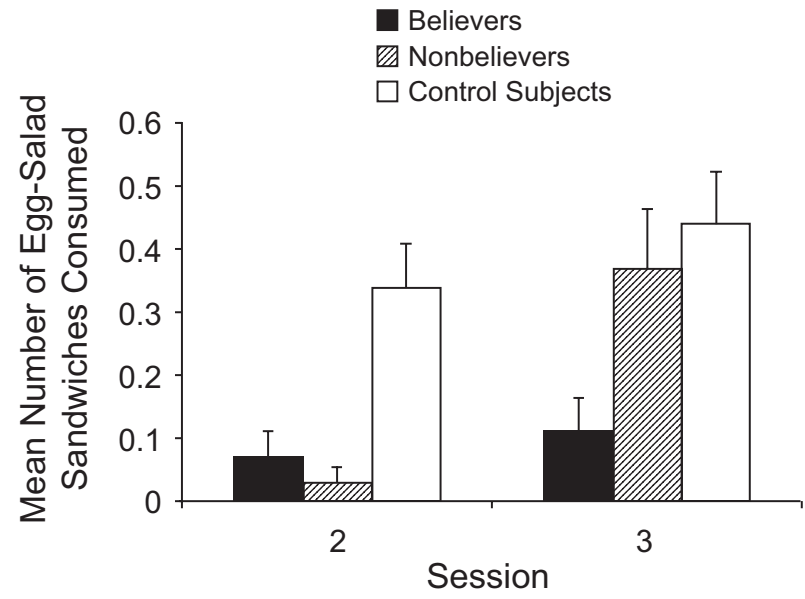

Fig. 2. Mean number of egg-salad sandwiches consumed by believers, nonbelievers, and control subjects in the second and third sessions. Error bars represent standard errors of the means.

subjects, $t(83)=3.02, p=.003, d=0.66$ (see Fig. 2). In both sessions, the three groups did not differ in their consumption of the other types of sandwiches, all $F_{\mathrm{s}}<1.38, p \mathrm{~s}>.25$.

\section{DISCUSSION}

This study shows that falsely suggesting that a person experienced a childhood event can change that person's behavior considerably, in both the short and the longer term. We falsely suggested to subjects that, as children, they had become ill after eating egg salad. After this manipulation, a significant minority of our subjects came to believe they had experienced this event. More important, this newfound autobiographical belief was accompanied by significantly reduced consumption of egg-salad sandwiches, both immediately and 4 months after the false suggestion.

Our findings show that, at least in the short term, simply having received the false feedback deterred both believers and nonbelievers from actually eating egg salad. Thus, they exhibited a contagion effect (Rozin \& Fallon, 1987). That is, all subjects who received the false feedback must have been reminded of what it must feel like to become ill after eating egg salad. This finding also indicates that suggestions about the past may have more persistent effects on behavior than on self-reports, at least in the short term. Such a dissociation between behavior and self-reports is a well-known phenomenon in social psychology (Greenwald et al., 2002).

However, in the third session, we found a significant difference between believers and nonbelievers in their consumption of egg-salad sandwiches. That is, the false feedback that was given 4 months earlier did not seem to have had a lasting effect on nonbelievers, who ate more egg-salad sandwiches than believers did at this session. It is possible that believers had been contemplating the egg-salad event and had consequently created memories about having gotten ill after eating egg salad as a child.

Of course, we cannot prove the falseness of the reports subjects provided. One could definitely claim that the manipulation triggered true memories rather than creating false ones. However, because we sought corroboration from subjects' parents, we can be fairly certain that the subjects whose data we analyzed did not experience the critical event when they were children.

Our findings demonstrate that it is possible, in at least a significant minority of adult subjects, to induce lasting false beliefs that have consequences not only for attitudes, but also for behavior (see also Scoboria, Mazzoni, \& Jarry, 2008). Scholars should consider this when conducting research on false beliefs, because some subjects might experience adverse outcomes from an experimentally induced false belief. These findings also have important implications for people's food and dieting choices. That is, possibly people could learn to avoid certain foods, and thus have healthier eating habits, by believing that they had negative childhood experiences with unhealthy foods. With overweight and obesity having reached epidemic levels around the world (Ogden et al., 2006), the influence of false beliefs on eating behavior seems an essential topic for future work, which should explore whether the consequences of actually having gotten sick after eating a food are similar to the consequences of having a false belief that one has experienced this event. Also, it would be interesting to investigate whether certain individual differences (e.g., suggestibility) may mediate or explain the effects on short- and long-term behavior that we found in this study. In any case, this study clearly demonstrates that false suggestions about childhood events can profoundly change people's attitudes and behavior.

Acknowledgments_Elke Geraerts was supported by a grant from the Netherlands Organization for Scientific Research (NWO 45107 004).

\section{REFERENCES}

Ajzen, I. (2005). Attitudes, personality, and behavior (2nd ed.). MiltonKeynes, England: Open University Press/McGraw-Hill.

Bernstein, D.M., Laney, C., Morris, E.K., \& Loftus, E.F. (2005a). False beliefs about fattening foods can have healthy consequences. Proceedings of the National Academy of Sciences, USA, 102, 13724-13731.

Bernstein, D.M., Laney, C., Morris, E.K., \& Loftus, E.F. (2005b). False memories about food can lead to food avoidance. Social Cognition, 23, 11-34.

Clancy, S.A. (2005). Abducted: How people come to believe they were kidnapped by aliens. Cambridge, MA: Harvard University Press.

Geraerts, E., Schooler, J., Merckelbach, H., Jelicic, M., Hauer, B.J.A., \& Ambadar, Z. (2007). The reality of recovered memories: Corroborating continuous and discontinuous memories of childhood sexual abuse. Psychological Science, 18, 564-568.

Greenwald, A.G., Banaji, M.R., Rudman, L.A., Farnham, S.D., Nosek, B.A., \& Mellott, D.S. (2002). A unified theory of implicit atti- 
tudes, stereotypes, self-esteem, and self-concept. Psychological Review, 109, 3-25.

Herman, C.P., \& Polivy, J. (1980). Experimental and clinical aspects of restrained eating. In A. Stunkard (Ed.), Obesity: Basic mechanisms and treatment (pp. 208-225). Philadelphia: W.B. Saunders.

Hyman, I.E., Husband, T.H., \& Billings, F.J. (1995). False memories of childhood experiences. Applied Cognitive Psychology, 9, 181195.

Laney, C., Bowman Fowler, N., Nelson, K.J., Bernstein, D.M., \& Loftus, E.F. (in press). The persistence of false beliefs. Acta Psychologica.

Loftus, E.F. (2005). Planting misinformation in the human mind: A 30-year investigation of the malleability of memory. Learning and Memory, 12, 361-366.

Loftus, E.F., \& Davis, D. (2006). Recovered memories. Annual Review of Clinical Psychology, 2, 469-498.

Loftus, E.F., \& Pickrell, J.E. (1995). The formation of false memories. Psychiatric Annals, 25, 720-725.

McNally, R.J., Lasko, N.B., Clancy, S.A., Macklin, M.L., Pitman, R.K., \& Orr, S.P. (2004). Psychophysiological responding during scriptdriven imagery in people reporting abduction by space aliens. Psychological Science, 15, 493-497.

Morris, E.K., Laney, C., Bernstein, D.M., \& Loftus, E.F. (2006). Susceptibility to memory distortion: How do we decide it has occurred? American Journal of Psychology, 119, 255-276.
Ogden, C.L., Carroll, M.D., Curtin, L.R., McDowell, M.A., Tabak, C.J., \& Flegal, K.M. (2006). Prevalence of overweight and obesity in the United States, 1999-2004. Journal of the American Medical Association, 295, 1549-1555.

Peters, M.J.V., Horselenberg, R., Jelicic, M., \& Merckelbach, H. (2007). The false fame illusion in people with memories about a previous life. Consciousness and Cognition, 16, 162-169.

Raymaekers, L. (2005). Using doctored photographs to study false memories for neutral/positive and negative events. Unpublished bachelor's thesis, Maastricht University, Maastricht, The Netherlands.

Rozin, P., \& Fallon, A.E. (1987). A perspective on disgust. Psychological Review, 94, 23-41.

Scoboria, A., Mazzoni, G., \& Jarry, J.L. (2008). Suggesting childhood food illness results in reduced eating behavior. Acta Psychologica, 128, 304-309.

Scott, S. (2001). The politics and experience of ritual abuse: Beyond disbelief. Buckingham, England: Open University Press.

Wade, K., Garry, M., Read, J.D., \& Lindsay, D.S. (2002). A picture is worth a thousand lies: Using false photographs to create false childhood memories. Psychonomic Bulletin \& Review, 9, 597-603.

(RECEIVED 1/5/08; REVISION ACCEPTED 3/20/08) 